\title{
Explaining IT Outsourcing Satisfaction using Domberger's Theory: An SME Perspective
}

\author{
Ching-Seng Yap \\ Graduate School of Business, Universiti Tun Abdul Razak, Kuala Lumpur, Malaysia \\ Yet-Mee Lim \\ Department of International Business, Faculty of Accountancy and Management, Universiti Tunku Abdul Rahman, \\ Selangor, Malaysia \\ Teck-Heang Lee \\ Department of Business Studies, Help University, Kuala Lumpur, Malaysia
}

\begin{abstract}
IT outsourcing has emerged as an important tool for enabling organizations to gain access to specific skills and services, focus on their core competencies, and reduce the cost of IT service provision. With the increasing number of IT outsourcing failures, it is timely to identify the determinants of IT outsourcing satisfaction. This study investigates the types of IT function outsourced and examines the factors influencing customer satisfaction in IT outsourcing in Malaysian small- and medium-enterprises. Using an email questionnaire survey, data are collected from 100 firms listed on the Directory of Small and Medium Enterprises in Malaysia. Drawing from Domberger's Theory of the Contracting Organization, four hypotheses are developed and tested in this study. Using the PLS path modelling technique, the findings show that focus on core competency, cost reduction, access to IT expertise and skills, and flexibility are positively related to customer satisfaction in IT outsourcing. The paper includes implications and recommendations for future studies.
\end{abstract}

Abstrak: IT outsourcing telah ada sebagai sarana penting untuk organisasi memungkinkan mendapatkan akses ke pelayanan yang berkeahlian khusus, fokus pada kompetensi inti mereka, dan mengurangi biaya penyediaan layanan TI. Dengan meningkatnya jumlah kegagalan IT outsourcing, inilah saatnya untuk mengidentifikasi faktor-faktor penentu kepuasan outsourcing IT. Studi ini mengkaji jenis fungsi TI outsourcing dan meneliti faktor yang mempengaruhi kepuasan pelanggan dalam outsourcing TI di perusahaan-perusahaan menengah-kecil di Malaysia. Survei dilakukan dengan menggunakan kuesioner melalui email, dan data dikumpulkan ada 100 dari perusahaan yang terdaftar di direktori perusahaan kecil dan menengah di

Acknowledgement: The authors would like to thank Chong Vei Soon, Ong Jwee Von, Ong Li Chian, and Yin Yee Loon for data collection.

Corresponding authors. E-mail: lee.teck.heang@help.edu.my

ISSN: $1141-1128$

http://www.gamaijb.mmugm.ac.id/ 
Malaysia. Mengacu dari teori Domberger tentang kontrak organisasi, empat hipotesis yang dikembangkan dan diuji dalam penelitian ini menggunakan teknik PLS path modeling. Temuan menunjukkan bahwa fokus pada kompetensi inti, adalah pengurangan biaya, akses ke keahlian TI dan keterampilan, serta fleksibilitas yang positif yang berhubungan dengan kepuasan pelanggan dalam IT outsourcing. Dalam makalah ini terdapat implikasi dan rekomendasi untuk studi masa depan.

Keywords: customer satisfaction; Domberger's Theory; Malaysia; IT outsourcing; SMEs 


\section{Introduction}

Information technology (IT) outsourcing has emerged as an important tool for enabling organizations across the globe to gain access to specific IT skills and services, focus on their core competencies, and reduce the cost of IT services (Seddon et al. 2007). Business organizations are greatly impacted by the IT global sourcing phenomenon that became highly visible after Kodak outsourced its data center operations in 1989 and has since grown rapidly to encompass offshoring and domestic outsourcing (King 2007). In order to meet rapidly changing technology trends with lower costs and higher quality, business organizations tend to rely on external vendors and contractors to manage and maintain their IT functions.

More organizations in Malaysia choose to outsource, a trend that see the Malaysian outsourcing industry is expected to be worth \$1.9 billion by 2013 (Outsourcing Malaysia 2010). With over 130 shared services and outsourcing (SSO) companies registered with MSC Malaysia and 250 call centers, Malaysia has been ranked third best location globally for SSO services for the past seven years (The 2011 Global Services Location Index [GSLI 2011]) by A.T. Kearney. According to an IDC report, the key growth areas for the Malaysian IT outsourcing industry are Business Process Outsourcing (BPO), Systems Integration (SI) and IT Consulting. In addition, outsourcing has been identified as the key element in the Business Services Lab, one of the 12 National Key Economic Areas (NKEA) under the Economic Transformation Programme initiated by the Prime Minister of Malaysia.

Types of IT functions commonly outsourced involves either technological resources or the entire infrastructure. This in- cludes hardware, software, communications systems, and human resources with managers, programmers, systems administrators, maintenance and related personnel involved in the design, maintenance and operation of the overall IT infrastructure (Loh and Ventkatraman 1992). As the IT functions may comprise many activities, from the vendor's perspective, it is important to minimize complaints and dissatisfaction as well as the cost of a service recovery plan. It is also important for vendors to track the direct feedback from customers on their responses to complaints and dissatisfaction (Abubakar et al. 2001).

According to the survey conducted by Kakabadse and Kakabadse (2002), satisfaction over with outsourcing providers has decreased from 79 percent to 62 percent. The growing dissatisfaction over the quality of outsourced services has resulted in a record number of renegotiations and number of buyers prematurely terminating an outsourcing relationship (Frauenheim 2005). Moreover, Knights (2007) found that 61 percent of outsourcing buyers placed more emphasis on setting up their outsourcing contract than on managing it, making it a major factor leading to dissatisfaction. The areas of complaint include the wrong provider is contacted, the levels of services provided, the service guarantees and the relationship of service purchaser/service provider.

Although IT outsourcing has become one of the important research areas in business, the studies on IT outsourcing have been mainly focused on large firms (Collins and Millen 1995; Fisher et al. 2008) or in western countries (Al-Qirim 2003; Dibbern and Heinzl 2009). Findings from these studies may not be generalized across the smaller firms in the emerging economies. On the other hand, past studies on ICT outsourcing 
practices among smaller firms mainly focused on determinants of outsourcing strategy (Rohde 2004); partnership quality (Ren et al. 2010); and outsourcing service provider selection (Chang et al. 2012). The studies on IT outsourcing satisfaction are limited. As small and medium-sized enterprises (SMEs) form the majority of business entities, it is therefore timely to study the customer satisfaction with IT outsourcing among SMEs in the emerging economy. This study aims to identify the types of IT functions frequently outsourced, to investigate the level of customer satisfaction in IT outsourcing and to examine the factors influencing the satisfaction of IT outsourcing among SMEs in Malaysia.

\section{Literature Review}

\section{IT Outsourcing}

Traditional information systems required a lot of resources for management, development and maintenance. Companies can grow by creating values using their core competency. Therefore, they would rather concentrate their resources on core competitive power than IT maintenance and management (Terdiman and Berg 2001). It is due to these circumstances that IT outsourcing has gained much popularity in various industries. The fundamental principle of IT outsourcing rests with the purchase of services or products through continuous interactions between parties (i.e. buyer and seller) to an agreement. Such interactions can be temporary or designated within an agreed length of time (Kern et al. 2002).

Malaysia is considered as one of the attractive locations for offshore outsourcing contracts due to its strong infrastructure and multilingual skills (Bernama 2010). According to Kasim (2005), there is an increase in popularity of IT outsourcing among government agencies as well as the public in Malaysia. This is despite the fact that finances are inadequate and skilled resources are limited. Both public and private sectors in Malaysia are witnessing an increasing trend in engaging in IT outsourcing relationships particularly in the amount of deals. For instance, large local IT outsourcing contracts include the RM1.3 billion Maybank deal, the RM440 million Malaysian Airline System Bhd (MAS) deal, and Permodalan Nasional Bhd's (PNB) RM32 million extension contract (Chong 2003).

\section{Domberger's Theory of Contracting Organization (1998)}

In 1998, Domberger wrote a book entitled "The Contracting Organization" which is based on his 15 years of empirical studies on the economic incentives gained by organizations that contracted out services. In his repeated studies, he found that organizations that contracted out service provision were able to save about 20 percent of cost without compromising service quality. The contracting out service provision included refuse collection, managing prisons and water treatment. Seddon, Cullen, and Willcocks (2007) linked the underlying benefits of contracting out service provision in the context of IT outsourcing and the subsequent customer satisfaction in purchasing organizations. The benefit drivers include specialization, market discipline, flexibility and cost savings. Domberger (1998) found that when firms contract out what they are not good at, they can devote their energies to doing more of what they are good at, which benefits both parties. By contracting out services, the ser- 
vice provided benefits from specialization and economies of scales, while purchasing firms benefit from greater revenue and profit by offering better quality and lower cost of product and service in its own market place. This was exemplified by the case of IBM and AT\&T. Purchasers have access to more expert knowledge and skills, specifically for the smaller firms. Smaller firms would need to spend less time and efforts on trying out something they are not good at which results in fewer pilot projects and less mistakes by the firms (Seddon et al. 2007). Flexibility can be achieved by dividing a big project into many smaller contracts with different providers for shorter time periods, or moving from a fixed to more variable cost of services provision (Seddon et al. 2007). This was exemplified by the deal between American Express and IBM in 2002. In the case of smaller firms, they may benefit from increased revenue and profitability if they are able to concentrate on their own core business and have access to expert knowledge and skills. The smaller firms may also find it easier to engage with different vendors for different services than building and maintaining services in-house. This arrangement will also reduce the management of internal staff. A point to note is that the explanation of Domberger's theory is not specific to ICT outsourcing and the benefit and cost measurements are different from those of conventional financial analysis.

\section{Customer Satisfaction in IT Outsourcing}

Satisfaction is viewed as a possible antecedent of customer behavior, while customer profitability is viewed as a performance outcome (from the supplier's point of view) of customer behavior (Söderlund and Vilgon 1999). The most critical success factor for an outsourcing relationship is that the provider should understand the client's objectives and goals (Claver et al. 2002). It is commonly found that customer satisfaction as an important antecedent to customer retention and thus long-term customer relationships (Anderson et al. 1994; Buttle 1996; Rust et al. 1995).

IT outsourcing customer satisfaction is determined by the customer's perceived evaluation of the IT services provided by IS company (Kim et al. 2003). Yoon and Im (2008) viewed customer satisfaction in a broader sense encompassing a perceived evaluation of products and services. In IT outsourcing environments, customers' requirements and feedback are essential to the development of IS applications and the enhancement of the service quality of IT service vendors or companies. They further classify IT outsourcing customer satisfaction as having five evaluation factors: consulting service quality, maintenance and repair, education, Service Level Agreement (SLA) quality and information quality. 


\section{Conceptual Framework and Hypotheses Development}

As shown in Figure 1, the conceptual framework of IT outsourcing satisfaction for this study is developed from Domberger's Theory of Contracting Organization and other IT outsourcing research.

Seddon et al. (2007) view focus on core competencies as an important driver of satisfaction. In order to focus on core competencies, firms outsource less critical activities on their value chains to outside vendors or suppliers. Resources are typically redirected to where they make the greatest positive impact, namely the organization's core functions (Tukel et al. 2006). From the resource-based view, the core competences approach provides a more complete model for explaining outsourcing. According to the approach, a company should pay attention to its core competencies since it gives the company growth and direction (Peteraf 1993), and at the same time outsource other non core service activities (Prahalad and Hamel 1990). Therefore, we hypothesize that:

\section{$H_{1}$ : A positive relationship exists between focus on core competencies and IT outsourcing customer satisfaction.}

Outsourcing IT functions to a more specialized subcontracted service provider who deals with many different clients will reduce cost significantly through economies of scale (Huff 1991). This view is supported by many prior studies that identify achieving greater economies of scale as the main reason for outsourcing (Kakabadse and Kakabadse 2002). Efficiency will be improved in terms of hardware, software and staff for the client company that outsource. Outsourcing will reduce production costs as well as investment cost in facilities and equipment (Due 1992). Therefore, we hypothesize that:

\section{$H_{2}: A$ positive relationship exists between cost re- duction and IT outsourcing customer satisfac- tion.}

Figure 1. Conceptual Framework of IT Outsourcing Satisfaction

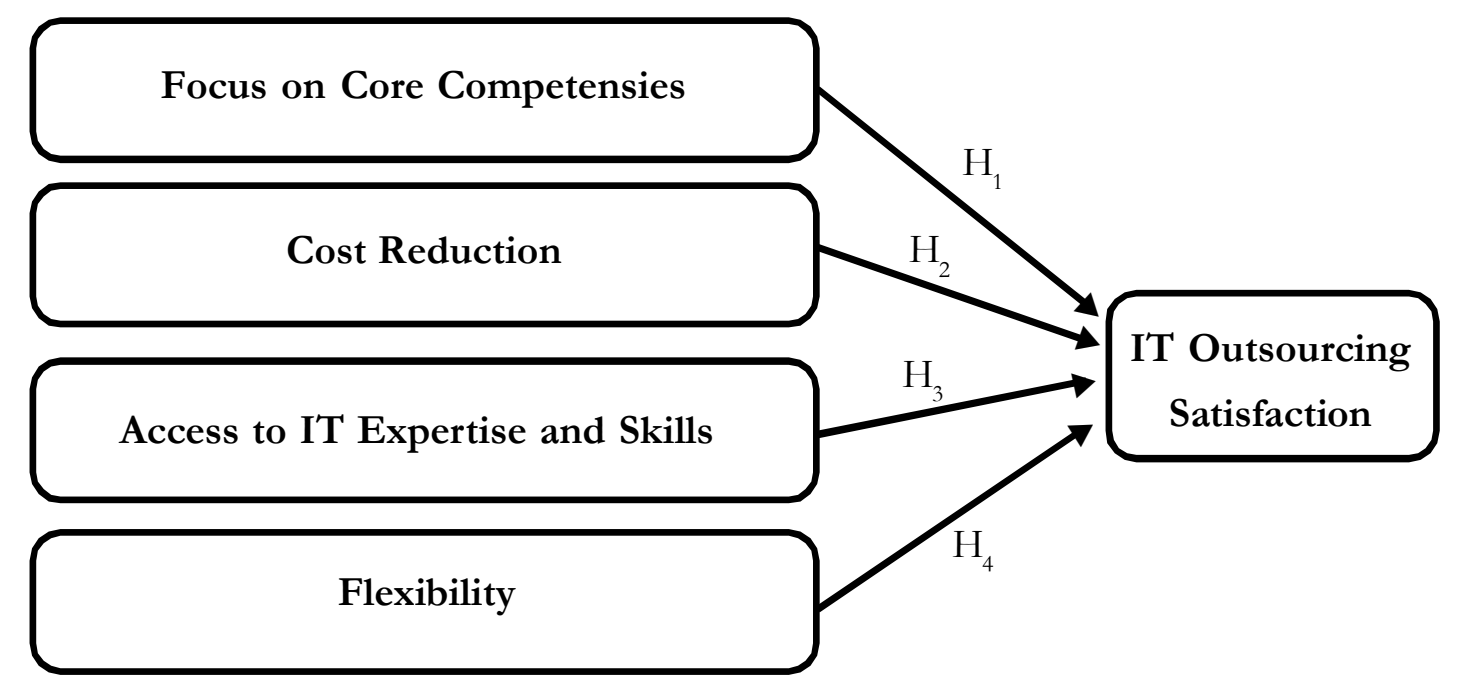

Adapted from Seddon et al. (2007). Does Domberger's Theory of ‘The Contracting Organization' explain why organizations outsource IT and the levels of satisfaction achieved? European Journal of Information Systems 16: 234-253. 
Both in-house staff and outsourced staff can retain and improve their technical skills through outsourcing (Ahles 2003). According to Wang and Yang (2006), outsourcing can facilitate immediate access to the latest technologies with the lead time customary in in-house development. This is because inhouse workers can attain the necessary knowledge on new technology of software management and development from the vendor. Wang and Yang (2006) also asserted that outsourcing is the fastest and most effective means to get qualified IT workers. In addition, access to better IT expertise and skills was found to be an important driver of IT outsourcing satisfaction by Seddon et al. (2007). Therefore, we hypothesize that:

\section{$H_{3}$ : A positive relationship exists between access to}

IT expertise and skills and IT outsourcing customer satisfaction.

Conventionally, flexibility in outsourcing is managed mainly through careful contracting. This is because management is often advised to craft short-term, airtight contracts to control for anticipated changes (Tan and Sia 2006). Flexibility deems to be a critical reason not just from a scale point of view but also the scope of product or service. Organizations need to provide a swift response to customer requirements and outsourcing is a means to go about it (Tukel et al. 2006). To deal with the present dynamic business environment, an outsourcing relationship should be able to handle such adaptation. Therefore, flexibility in outsourcing is primarily concerned with the ability of an outsourcing relationship to change the extent, nature, or scope of business services delivered (Tan and Sia 2006). Therefore, we hypothesize that:

$H_{4}: A$ positive relationship exists between flexibility and IT outsourcing customer satisfaction.

\section{Methods}

\section{Sample}

The sample of this study consists of SMEs who play an important role in the Malaysian economy and are considered to be the backbone of industrial development in the country (Saleh and Ndubisi 2006). According to Census on Establishment and Enterprise (2005), 99.2 percent or 518,996 of the enterprises in Malaysia are SMEs. However, SMEs only contributes 24 percent of the gross domestic product (GDP) when in countries such as South Korea, Taiwan and Japan they contribute up to 60 percent. The reason could be partly attributed to many SMEs not making use of ICT in the way they do in other countries (Koh 2008).

The target population of the study is all the SMEs from various industry categories located in the Klang Valley. The selection of Klang Valley in this study is based on the reason that 50 percent of the SMEs are concentrated in this region. We first obtained the list of SMEs that operate in Klang Valley from the SME Corporation Malaysia (SMECORP) website (www.smecorp. gov.my). Next, the SMEs listed on the website must have an active e-mail address. Finally, a total of 3,654 SMEs with active e-mail addresses are obtained. Email questionnaires are used to collect primary data as it is a convenient and cost effective method. Of the total number of emails sent out, 100 SMEs returned usable responses, generating a response rate of 2.7 percent. All of the respondents are SMEs that had outsourced their IT services. As shown in Table 1, nearly half $(49 \%)$ of the SMEs are service firms, while slightly over a quarter $(28 \%)$ of them are manufacturing and manufacturing-related firms. The remaining respondents consist of 
those from construction (11\%), primary agriculture $(3 \%)$ and other sectors $(9 \%)$. More than half $(60 \%)$ of the SMEs have been in operations for less than or equal to 10 years, 27 percent are between 11 to 20 years, 8 percent is-are between 21 to 30 years and 5 percent is are above 30 years. Slightly over half $(53 \%)$ of the respondents hold the position of director while one-third are managers $(33 \%)$.

Table 1. Demographic Variables $(\mathbf{N}=\mathbf{1 0 0})$

\section{Variables and Measurement}

The questionnaire is divided into three sections. Section A consists of 15 items to gather data pertaining to factors that drive IT outsourcing satisfaction. Section B consists of 23 items to collect data about satisfaction towards IT outsourcing services. Section $\mathrm{C}$ is information on the demographic variables of SMEs and the type of IT func-

\begin{tabular}{|c|c|c|}
\hline Variable & Frequency & Percentage \\
\hline \multicolumn{3}{|l|}{ Industry Sector } \\
\hline Primary Agricultural & 3 & 3 \\
\hline Manufacturing Related Services & 25 & 25 \\
\hline Manufacturing (including Agro-based) & 3 & 3 \\
\hline Construction & 11 & 11 \\
\hline Services & 40 & 40 \\
\hline Others & 9 & 9 \\
\hline \multicolumn{3}{|l|}{ Duration of Operation } \\
\hline 10 years and below & 60 & 60 \\
\hline $11-20$ years & 27 & 27 \\
\hline 21-30 years & 8 & 8 \\
\hline Above 30 years & 5 & 5 \\
\hline \multicolumn{3}{|l|}{ Position } \\
\hline Director & 53 & 53 \\
\hline Manager & 33 & 33 \\
\hline Others & 14 & 14 \\
\hline \multicolumn{3}{|l|}{ Type of IT Outsourcing } \\
\hline ERP & 8 & 8 \\
\hline CRM & 11 & 11 \\
\hline BPR & 22 & 22 \\
\hline PC Management & 44 & 44 \\
\hline Network and communications services & 48 & 48 \\
\hline IT infrastructure & 48 & 48 \\
\hline IT security services & 18 & 18 \\
\hline Help desk support & 21 & 21 \\
\hline Website hosting & 41 & 41 \\
\hline Data centre operation & 14 & 14 \\
\hline Others & 6 & 6 \\
\hline
\end{tabular}


tion outsourced. All items are adapted from pre-validated instruments of prior related research. The four factors that drive the SMEs to outsource are focus on core competencies, cost reduction, access to expertise and skills, and flexibility. Focus on core competencies is operationalized as having 3 items adapted from Torkkeli and Tuominen (2002). Cost reduction is measured using 4 items adapted from Beaumont and Sohal (2004), Gonzalez, Gasco and Llopis (2005), and Wang and Yang (2006). Access to IT expertise and skills consists of 4 items adapted from Wang and Yang (2006), and Gonzales, Gasco, and Llopis (2005). To evaluate the flexibility factor, this study uses 4 items adapted from Graham and Scarborough (1997), and Tan and Sia (2006). In section $\mathrm{B}$, the 23 items for assessing the IT outsourcing satisfaction are adapted from Yoon and Im (2008). The IT outsourcing satisfaction construct consists of four dimensions, which are consulting service quality, maintenance and repairing services, service level agreement quality, education service, and information service. Respondents are asked to assess a total of 38 items by indicating their agreement with statements using a five-point Likert scale, ranging from 1 strongly disagree to 5 - strongly agree. In addition, based of prior related studies, 10 types of IT function ranging from IT security services, hardware infrastructure, web hosting, to call centre operation are listed for respondents to check the IT functions they outsource.

\section{Results}

Generally, the respondents perceived the items asked in the questionnaire positively. Based on the descriptive analysis, the mean values of all factors show that respon- dents tend to agree with the statements in the questionnaire. As for the IT outsourcing satisfaction construct, the mean value of 3.57 indicates a moderate level of satisfaction for their IT outsourcing solution. As shown in Table 2, the reliability test shows that all five constructs achieve the Cronbach's alpha score of more than 0.60 , indicating an acceptable level of internal consistency. The correlation coefficients between the independent variables are significant, ranging from 0.24 to 0.60. Further collinearity diagnostic analysis did not find any potential multicollinearity problem among the independent variables. The top three IT functions outsourced by the SMEs are network and communications services, IT infrastructure, and PC management. A majority of the respondent (92\%) outsourced less than five IT services listed in the questionnaire and only two respondents outsourced all the IT services. The average number of IT services outsourced stands at three.

The data are analyzed using PLS path modeling (Smart PLS 2.0 M3) which involves the assessment of measurement model and structural model. The assessment of the measurement model includes reliability, convergent validity and discriminant validity tests (Fornell and Bookstein 1982). Reliability is assessed using Cronbach's alpha and composite reliability scores, and both require a minimum score of 0.70 as satisfactory. Convergent validity is assessed using factor loadings with a minimum value of 0.50 . While discriminant validity at the item level is assessed by comparing the own factor loadings with cross factor loadings. The own factor loading is expected to be higher than its cross-loading in order to achieve discriminant validity. At the construct level, discriminant validity is assessed by comparing the square roots of AVE of each construct and its correlation 
Yap etal.

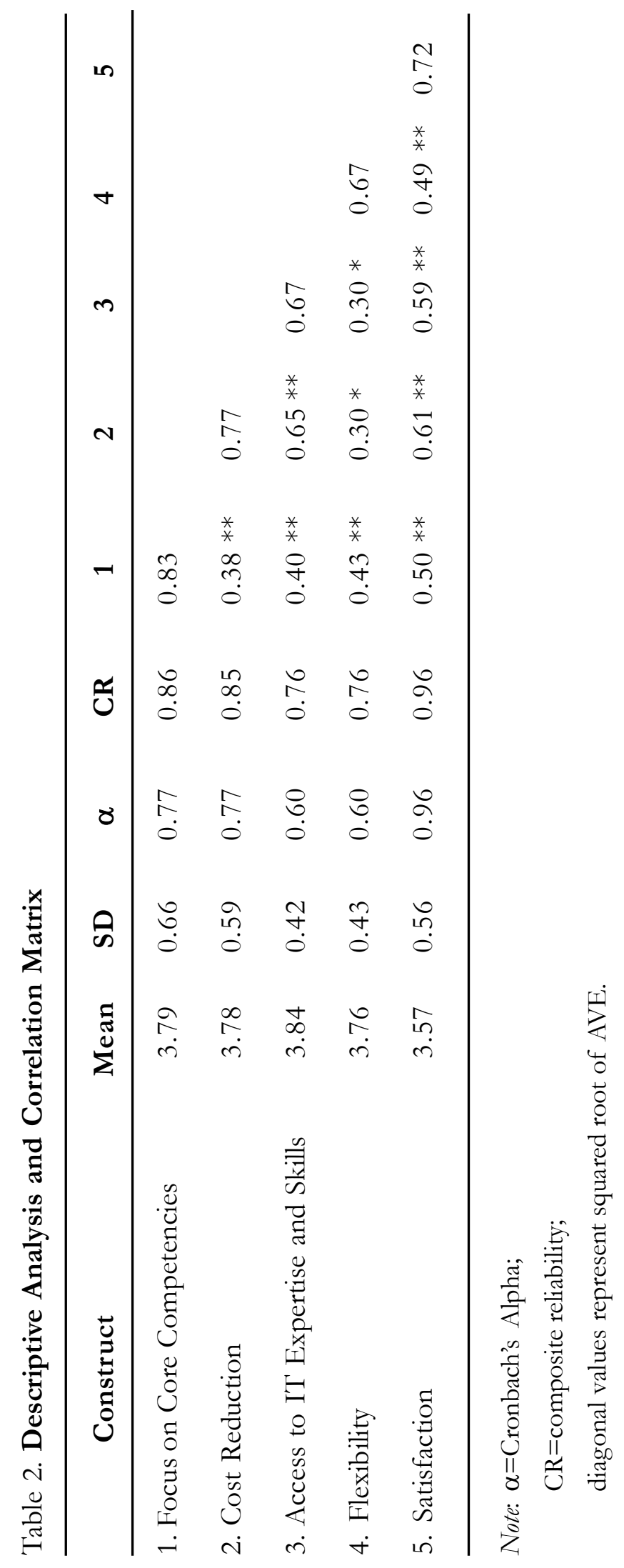


with other constructs. To indicate adequate discriminant validity, the latter should be larger than the former. As shown in Table 2, all composite reliability scores are higher than 0.7, signifying adequate reliability. Factor loadings and cross loadings are shown in Table 3, where all loadings are above 0.50 and loaded higher within the own factor and loaded lower on other factors, signifying adequate convergent and discriminant validity at the item level. All squared roots of AVE are larger than the correlations between constructs, also signifying adequate discriminant validity at the construct level. These tests suggest that all items have sufficient reliability, convergent validity and discriminant validity.
Assessment of the structural model involves testing of hypotheses in terms of effect size, direction and significance. All four factors are found to be significantly related to IT outsourcing satisfaction as shown in Table 3. For $\mathrm{H}_{1}$, focus on core competencies is positively related to IT outsourcing satisfaction $(\beta=0.183$; $p<0.05)$. Information technology function in an SME may be perceived as less critical activities, thus firms outsource less critical activities on their value chains to outside providers or suppliers (Prahalad and Hamel 1990). By outsourcing these less critical activities, SMEs are able to focus on their core functions which they know best and have higher satisfaction toward IT outsourcing. The finding is consistent with that of Torkkeli and Tuominen (2002), and Seddon et al. (2007).

Table 3. Factor Loadings and Cross Loadings

\begin{tabular}{lllll}
\hline & CORE & COST & SKILL & FLEX \\
\hline Core1 & $\mathbf{0 . 8 5}$ & 0.29 & 0.36 & 0.35 \\
Core2 & $\mathbf{0 . 7 8}$ & 0.33 & 0.35 & 0.35 \\
Core3 & $\mathbf{0 . 8 5}$ & 0.33 & 0.29 & 0.36 \\
Cost1 & 0.31 & $\mathbf{0 . 7 1}$ & 0.46 & 0.15 \\
Cost2 & 0.18 & $\mathbf{0 . 7 4}$ & 0.50 & 0.16 \\
Cost3 & 0.31 & $\mathbf{0 . 7 9}$ & 0.38 & 0.29 \\
Cost4 & 0.34 & $\mathbf{0 . 8 2}$ & 0.62 & 0.29 \\
Skill1 & 0.30 & 0.56 & $\mathbf{0 . 7 6}$ & 0.27 \\
Skill2 & 0.11 & 0.34 & $\mathbf{0 . 5 4}$ & 0.09 \\
Skill3 & 0.16 & 0.27 & $\mathbf{0 . 5 3}$ & 0.14 \\
Skill4 & 0.40 & 0.49 & $\mathbf{0 . 8 0}$ & 0.22 \\
Flex1 & 0.19 & 0.17 & 0.08 & $\mathbf{0 . 5 7}$ \\
Flex2 & 0.38 & 0.21 & 0.15 & $\mathbf{0 . 6 0}$ \\
Flex3 & 0.27 & 0.12 & 0.23 & $\mathbf{0 . 6 4}$ \\
Flex4 & 0.32 & 0.27 & 0.29 & $\mathbf{0 . 8 5}$ \\
\hline
\end{tabular}


For $\mathrm{H}_{2}$, cost reduction has a positive relationship with IT outsourcing satisfaction $(\beta=0.307 ; p<0.05)$. As the SMEs may not have the available resources to operate the IT functions in their firms, they will have to incur more cost to get the necessary infrastructure to support the IT functions (Due 1992). Therefore, the SMEs may outsource the IT functions to IT providers that have the resources to manage the IT functions of the SMEs. Besides, outsourcing to these IT providers will help SMEs reduce cost significantly through economies of scale. By having a pool of clients, IT providers can perform a significant amount of tasks at a lower price (Huff 1991). When SMEs perceived that the IT outsourcing could reduce cost, their satisfaction for IT outsourcing increases. The finding is parallel to that of Lacity and Willcocks (1998), and Kakabadse and Kakabadse (2002).

For $\mathrm{H}_{3}$, access to IT expertise and skills is positively related to IT outsourcing satisfaction $(\beta=0.244 ; p<0.05)$. This result indicates that the SMEs may not have the IT specialists to run their IT functions as their business is operated at a small and medium scale and might not have sufficient budget allocation on IT. Therefore, SMEs might outsource their IT function to gain access to a pool of specialists with expertise and skills in managing IT functions. Through outsourcing, SMEs do not have to pay for the IT specialist's salary thus it may reduce overhead costs to the firm (Yang and Huang 2000). As such, as the ability to access expertise and skills increases, the level of IT outsourcing satisfaction also increases. The finding is consistent with the study of Seddon et al. (2007).

For $\mathrm{H}_{4}$, the analysis shows a positive relationship between flexibility and IT outsourcing satisfaction $(\beta=0.248 ; p<0.05)$. Flexibility in terms of the ability to shift to other IT providers when the need arises to protect them from further risk of outsourcing to the same vendor, may help SMEs in reducing their budget on the IT services (Graham and Scarborough 1997). This could be due to SMEs' ability to segregate their IT functions into different parts and outsource those to different vendors that are able to provide these functions at the best price. As such, the more flexible the IT outsourcing agreement, the more satisfied the SMEs are. The finding is consistent with the study of Tukel, Kremic, and Rom (2006).

In summary, the analysis shows that the data support all the hypotheses tested in the study. Collectively, the four factors contribute 54.6 percent of the total variance explained for IT outsourcing satisfaction in the model. Cost reduction is the most important driver of IT outsourcing satisfaction, followed by flexibility, access to IT expertise and skills, and focus on core competencies albeit only a marginal difference exists between the four drivers. 
Table 4. Summary of Hypothesis Testing

\begin{tabular}{llccc}
\hline \multicolumn{1}{c}{ Hypothesized Relationship } & Beta & t-value & Result \\
\hline $\mathrm{H}_{1} \quad \begin{array}{l}\text { Focus on Core Competencies } \rightarrow \text { IT } \\
\text { Outsourcing Customer Satisfaction }\end{array}$ & 0.183 & 2.596 & Supported \\
$\mathrm{H}_{2} \quad \begin{array}{l}\text { Cost Reduction } \rightarrow \text { IT } \\
\quad \text { Outsourcing Customer Satisfaction }\end{array}$ & 0.307 & 3.086 & Supported \\
$\mathrm{H}_{3} \quad \begin{array}{l}\text { Access to IT Expertise and Skills } \rightarrow \text { IT } \\
\text { Outsourcing Customer Satisfaction }\end{array}$ & 0.244 & 2.394 & Supported \\
$\mathrm{H}_{4} \quad \begin{array}{l}\text { Flexibility } \rightarrow \text { IT } \\
\quad \text { Outsourcing Customer Satisfaction }\end{array}$ & 0.248 & 3.213 & Supported \\
\hline
\end{tabular}

\section{Conclusion}

The findings of this research are two folds. Firstly, the findings show that all the factors tested in the hypotheses -focus on core competencies, cost reduction, access to expertise and skills, and flexibility- have a positive relationship with IT outsourcing satisfaction. Contrary to the findings of Seddon et al. (2007), cost reduction and flexibility are found in this study to be the significant determinants of IT outsourcing satisfaction among SMEs in Malaysia. The findings provide support for Domberger's theory in the context of IT outsourcing satisfaction. It can be argued that cost reduction is of utmost importance among SMEs as far as an IT outsourcing decision is concerned, as other determinants such as focus on core competencies and flexibility will ultimately lead to cost benefits. Secondly, IT outsourcing service providers in Malaysia should focus on cost benefits when providing the IT services to SMEs. The four factors have almost equal importance in determining the IT outsourcing satisfaction.
The study suffers from small sample size when trying to make generalization across the population. As such, the results of this study serve-as the basis for preliminary findings about the drivers of IT outsourcing satisfaction among the Malaysian SMEs. Apart from this, the conceptualization of the determinants is mainly based on Domberger's four benefits of contracting. If other conceptualizations of constructs were used, the study could suggest different results. Therefore, it is recommended to future researchers that a larger sample size be included in order to make statistical inferences across the population. In addition, more drivers are to be tested to make meaningful comparisons on the relative importance of these drivers and potential moderators, mediators and competing models for IT outsourcing satisfaction in the SMEs context.

In conclusion, this study seeks to examine the relationship between factors that drive IT outsourcing and IT outsourcing satisfaction. With regard to this, the research findings are expected to provide more information about how customer satisfaction in 
IT outsourcing can be achieved among the SMEs in Malaysia. With the recent global financial crisis, we hope that more SMEs will embark on IT outsourcing to reap the ben- efits from it and enjoy the potential of accumulated expertise of the outsourcers while focusing on what they are good at.

\section{References}

Abu Bakar, B., F. Mavondo, and V. Clulow. 2001. Customer Satisfaction with Supermarket Retail Shopping. Retrieved August 20, 2010, from http://smb.vuw.ac.nz:

8081/WWW/ANZMAC2001/anzmac/AUTHORS/pdfs/Abubakae1.pdf.

Ahles, A. 2003. More U.S. high-tech firms shift jobs to India's cheaper, educated labor market. Knight Ridder Tribune Business News (July 21): 1.

Al-Qirim, N. A. 2003. The strategic outsourcing decision of IT and Ecommerce: The case of small businesses in New Zealand. Journal of Information Technology Cases and Applications 5 (3): 32-56.

Anderson, E. W., C. Fornell, and D. R. Lehmannn. 1994. Customer satisfaction, market share, and profitability: Findings from Sweden. Journal of Marketing 58: 53-66.

A.T. Kearney's. 2011. Global Services Location Index (GSLI) 2011. Retrieved February 11, 2011, form http:/ /www.atkearney.com/index.php/Publications/global-services-location-index-gsli.html

Beaumont, N., and C. Costa. 2002. Information technology outsourcing in Australia. Journal of Information Resources Management 15 (3): 14-31.

Bernama. 2010. Malaysia's outsourcing industry to grow between 15 and 20 percent. Bernama (July 9). Retrieved from http://bernama.com/bernama/v5/newsindex.php?id $=498772$

Boldea, I. 2006. A study of information technology outsourcing. Economy and Transformation Management International Conference e-Book. Retrieved July 29, 2010, from SSRN database.

Buttle, F. 1996. Relationship Marketing: Theory and Practice. London: Paul Chapman.

Chang, S.-I., D. C. Yen, C. S-P. Ng, and W-T. Chang. 2012. An analysis of IT/IS outsourcing provider selection for small- and medium-sized enterprises in Taiwan. Information and Management 49 (5): 199209.

Chong, Y. 2003. Growing trend in IT outsourcing. The Star (October 20). Retrieved August 20, 2010, from http://www.csc.com/my/news/7888-growing_trend_in_it_outsourcing

Claver E., R. González, J. Gascó, and J. Llopis. 2002. Information systems outsourcing: Reasons, reservations and success factors. Logistics Information Management 15 (4): 294-308.

Collins, J. S., and R. A. Millen. 1995. Information systems outsourcing by large American industrial firms: Choices and impacts, information resources. Management Journal 8 (1): 5-13.

Domberger, S. 1998. The Contracting Organization: A Strategic Guide to Outsourcing. Oxford, UK: Oxford University Press.

Due, R. T. 1992. The real costs of outsourcing. Journal of Information Systems Management 9: 78-81.

Fisher, J., R. Hirschheim, and R. Jacobs. 2008. Understanding the outsourcing learning curve: A longitudinal analysis of a large Australian company. Information Systems Frontiers 10: 165-178. 
Fornell, C., and D. F. Darker. 1982. Two structural equations models: LISREL and PLS applied to consumer exit-voice theory. Journal of Marketing Research 19 (4): 440-452.

Frauenheim, E. 2005. Offshore outsourcing satisfaction drops. CNET.com (June 7). Retrieved August 19, 2010, from http://news.cnet.com/Offshore-outsourcing-satisfaction-drops/2100-1022_35736170.html?hhTest=1

Graham, M., and H. Scarborough. 1997. Information technology outsourcing by state governments-in Australia. Journal of Public Administration 56 (3): 30-39.

Gonzalez, R., J. Gasco, and J. Llopis. 2005. Information systems outsourcing risks: A study of large firms, Journal of Industrial Management and Data Systems 105 (1): 45-62.

Huff, S. L. 1991. Outsourcing of information services. Business Quarterly: 62-65.

Kakabadse A., and N. Kakabadse. 2002. Trends in outsourcing: Contrasting USA and Europe. European Management Journal 20 (2): 189-198.

Kasim, S. 2005. Govt mulls ICT outsourcing. New Straits Times (March 10). Computimes.

Kern T., L. P. Willcock, and E. V. Heck. 2002. The winner's curse in IT outsourcing: Strategies for avoiding relational trauma. California Management Review 44 (2): 47-69.

Kim B., K. Park, and J. Kim. 2003. Satisfying different customer groups for IS outsourcing. Asia Pacific Journal of Marketing and Logistic 15 (3): 48-69.

King, W. R. 2007. The IS organization of the future: Impacts of global sourcing. Journal of Information Systems Management 24 (2): 121.

Knights, M. 2007. Outsourcing dissatisfaction runs high. CIO UK Magazine (March 21). Retrieved 12 December, 2010 from http://www.cio.co.uk/concern/budgets/news

/index.cfm?articleid $=1003$ andpn $=2$

Koh, C. 2008. Chance to compete in global market. The Star (November 24). Retrieved 30 November, 2010 from http://thestar.com.my/metro/story.asp?file=/2008/11/24/

north $/ 2606020 \& \mathrm{sec}=$ north

Loh, L., and N. Venkatraman. 1992. Diffusion of information technology outsourcing: Influence sources and the Kodak effect. Journal of Information System Research 3 (4): 334-358.

Outsourcing Malaysia. 2010. Malaysia Outsourcing Industry. Retrieved 15 August 2010, from http:// www.outsourcingmalaysia.org.my/facts-figures/71-malaysian-outsourcing-industry.php

Peteraf, M. A. 1993. The cornerstones of competitive advantage: A resource-based view. Strategic Management Journal 14: 179-191.

Prahalad, C. K., and G. Hamel. 1990. The core competence of the organization. Harvard Business Review 68 (3): 79-91.

Ren, S. J.-F., E. W. T. Ngai, and V. Cho. 2010. Examining the determinants of outsouring partnership quality in Chinese small- and medium-sized enterprises. International Journal of Production Research 48 (2): 453-475.

Rust, R. T., A. J. Zahorik, and T. L. Keiningham. 1995. Return on quality (ROQ): Making service quality financially accountable. Journal of Marketing 59 (2): 58-70.

Saleh, A. S., and N. O. Ndubisi. 2006. An evaluation of SME development in Malaysia. International Review of Business Research Papers 2 (1): 1-14. 
Seddon, P. B., S. Cullen, and L. P. Willcocks. 2007. Does Domberger's theory of the contracting organization' explain why organizations outsource IT and the levels of satisfaction achieved? European Journal of Information Systems 16: 234-253.

Small and Medium Industries Development Corporation (SMIDEC). 2009. Statistics Retrieved January 2, 2010, from http://www.smidec.gov.my/detailpage.jsp?page=statistics

Söderlund, M., and M. Vilgon. 1999. Customer satisfaction and links to customer profitability: An empirical examination of the association between attitudes and behavior. SSE/EFI Working Paper Series in Business Administration.

Tan, C., and S. K. Sia. 2008. Managing flexibility in outsourcing. Journal of the Association for Information System 7 (4): 179-206.

Terdiman, R., and T. Berg. 2001. Offshore Application Outsourcing. Stamford, CT: Gartner Group.

Torkkeli M., and M. Tuominen. 2002. The contribution of technology selection to core competencies. International Journal of Production Economics 77: 271-284.

Tukel, O. I., T. Kremic, and W. O. Rom. 2006. Outsourcing decision support: A survey of benefits, risks, and decision factors. Supply Chain Management: An International Journal 11 (6): 467-482.

Wang, J. J., and D. L. Yang. 2006. Using a hybrid multi-criteria decision aid method for information systems outsourcing. Journal of Computer and Operations Research 34: 3691-3700.

Yang, C., and J. Huang. 2000. A decision model for IS outsourcing. International Journal of Information Management 20 (3): 39-225.

Yoon, Y. K., and K. S. Im. 2008. Evaluating IT outsourcing satisfaction and its impact on firm performance in Korea. International Journal of Technology Management 43 (1-3): 160-175. 
